\title{
Helium isotope compositions of basaltic rocks from Dokdo and Ullengdo volcanic islands, South Korea
}

\author{
WONHEE LEE ${ }^{1}$, HYUNWOO LEE ${ }^{1}$, JONGUK KIM ${ }^{2}$, \\ JIHYE $\mathrm{OH}^{2}$, FINLAY M. STUART ${ }^{3}$ \\ ${ }^{1}$ Seoul National University \\ (*correspondence: schol212@snu.ac.kr) \\ ${ }^{2}$ Korea Institute of Ocean Science and Technology \\ ${ }^{3}$ Scottish Universities Environmental Research Centre
}

Dokdo and Ulleungdo (DU) are volcanic islands, formed by Cenozoic volcanism in the East Sea (Sea of Japan), a backarc basin of the Japanese arc. The DU rocks mainly range from alkali basalt to trachyte, and the ages are younger than $\sim 2.7 \mathrm{Ma}$ [1]. The origin of the DU magma is controversial. Previously OIB-like trace element patterns have been reported, suggesting the origin of magma is due to mantle plume activity [2]. However, according to the mantle tomography of this region, the presence of mantle plume originating from the lower mantle seems unlikely. In addition, it is recently believed that there is a stagnant slab underneath NE Asia to release water for the Cenozoic volcanism [3]. Although the helium isotope ratio $\left({ }^{3} \mathrm{He} /{ }^{4} \mathrm{He}\right)$ effectively indicates the origin of magma, studies on magma sources using helium isotopes in DU rocks have not been carried out, especially in mafic rocks. Here we report new results of the helium concentrations and ${ }^{3} \mathrm{He} /{ }^{4} \mathrm{He}$ ratios as well as whole-rock and mineral chemistry of subaerial and submarine volcanic rocks from DU. We used hand-picked olivine and clinopyroxene phenocrysts in the samples for helium isotope analysis, measured by a MAP 215-50 noble gas mass spectrometer. Whole-rock and mineral compositions were measured by XRF and EPMA, respectively. The wholerock compositions show the range of $\mathrm{SiO}_{2}$ from 44.88 to 51.27 wt\%, with $\mathrm{Mg \#}$ of olivine (76.2-83.9) and clinopyroxene phenocrysts $(71.7-88.4)$. The ${ }^{3} \mathrm{He} /{ }^{4} \mathrm{He}$ ratios range from 5.7 to 5.9 Ra for Dokdo and from 4.7 to $6.0 \mathrm{Ra}$ for Ulleungdo, respectively, with ${ }^{4} \mathrm{He}$ concentrations of all samples ranging from $2.8 \times 10^{-9}$ to $1.3 \times 10^{-8} \mathrm{ccSTP} / \mathrm{g}$. All samples show ${ }^{3} \mathrm{He} /{ }^{4} \mathrm{He}$ ratios which are similar to that of SCLM (6.1 Ra), but are more radiogenic compared to the MORB ( $8 \mathrm{Ra}$ ) and plume (>10 Ra) sources. Thus, the results show that the magma origin of DU is significantly influenced by SCLM rather than mantle plume, based on the ${ }^{3} \mathrm{He} /{ }^{4} \mathrm{He}$ ratios.

[1] Song et al. (2006) Jour. Petrol. Soc. Korea. 15, 72-80. [2] Tastumoto \& Nakamura (1991) GCA 55, 3697-3708. [3] Richard \& Iwamori (2010) PEPI 183, 280-287. 